\title{
KARAKTER TOKOH PADA NOVEL "MIDAH SI MANIS BERGIGI EMAS” KARYA PRAMOEDYA ANANTA TOER
}

\author{
Hidayati Desy, Sri Rahmawati \\ hidayati_desy@ymail.com \\ Akademi Maritim Nusantara Banjarmasin
}

Diserahkan: 29 Juli 2020, Direvisi: 29 April 2021, Diterima: 22 Juni 2021

\begin{abstract}
The specificity of novel "Sweet Midah the Gold Teeth" Pramoedya Ananta Toer's work located in the characters displayed each character. Of main character that comes from a religious family, but has the opposite character with his family background. Accordingly, this study raised the issue about the character. Based on data analysis, the results of this study it can be concluded that the figure could in the novel "Sweet Midah the Gold Teeth" Pramoedya Ananta Toer's work amounted to 14 people with varying character. Like, the main character of Midah the firm establishment, unruly, unyielding, not nimble, easily offended, like saving liver pain, and faithful.
\end{abstract}

Keywords: Figure, Character, Novel

\section{Abstrak}

Kekhasan novel "Midah si Manis Bergigi Emas" karya Pramoedya Ananta Toer terletak pada karakter yang ditampilkan tiap tokoh. Karakter tokoh utama yang berasal 
dari keluarga yang taat beragama tetapi mempunyai karakter yang berkebalikan dengan latar belakang keluarganya. Oleh karena itu, penelitian ini mengangkat masalah mengenai karakter tokoh. Berdasarkan analisis data, hasil penelitian menunjukkan bahwa tokoh yang terdapat dalam novel "Midah si Manis Bergigi Emas" Karya Pramoedya Ananta Toer berjumlah 14 orang dengan karakter yang bervariasi. Seperti, karakter tokoh utama Midah yaitu, teguh pendirian, tegar, pantang menyerah, tidak cekatan, mudah tersinggung, suka menyimpan rasa sakit hati, dan setia.

Kata kunci: Tokoh, Karakter Tokoh, Dan Novel

\section{PENDAHULUAN}

Tokoh berperan penting dalam sebuah cerita. Melalui tokoh, perwatakan setiap manusia digambarkan baik lewat dialog, gerak anggota tubuh, maupun cara berpikir. Tokoh protagonis digambarkan dengan karakter yang baik dan menarik simpati masyarakat, sedangkan tokoh antagonis mempunyai karakter yang berkebalikan atau bertentangan dengan pandangan masyarakat. Terkadang karakter tokoh dideskripsikan dengan sederhana oleh pengarang dan ditanggapi sederhana juga oleh pembaca. Hal sederhana yang dimaksud di sini adalah tokoh protagonis dibatasi pada tokoh yang mempunyai karakter ramah, jujur, dan sejumlah sifat-sifat baik lainnya, sedangkan tokoh antagonis adalah tokoh yang memiliki karakter sebaliknya. Dengan kata lain, tokoh antagonis merupakan tokoh yang kontra dengan tokoh protagonis atau tokoh yang menyebabkan konflik bagi tokoh protagonis.

Novel yang dikaji pada penelitian ini adalah novel "Midah si Manis Bergigi Emas" karya Pramoedya Ananta Toer. Novel ini dipilih karena berisi berbagai tingkah laku manusia dengan karakter yang khas dan selalu berkutat dengan masalah kemanusiaan, yaitu penderitaan, kegagalan, kebahagiaan, kekecewaan, dan perjuangan untuk hidup. Kekhasan novel ini terletak pada karakter yang ditampilkan tiap tokoh. Karakter tokoh utama yang berasal dari keluarga yang taat beragama tetapi mempunyai karakter yang 
berkebalikan dengan latar belakang keluarganya. Hal ini menjadi pelajaran bahwa karakter setiap orang berbeda-beda dan tidak harus mengikuti orang tuanya. Bertolak dari keterangan tersebut penelitian ini dilakukan. Karakter tokoh yang kuat, unik, berani berbeda dengan orang lain menjadi nilai tersendiri bagi peneliti untuk meneliti karakter-karakter tokoh yang terdapat pada novel ini. Selain itu, jalan ceritanya yang menarik dan konflik antar tokoh menjadikan novel ini dipilih. Novel ini juga bisa menjadi bahan bacaan bagi siswa pada Sekolah Menengah Atas (SMA) dilihat dari segi kebahasaan maupun dari segi isi cerita. Dengan adanya bacaan sastra seperti ini, dapat membuka wawasan siswa mengenai masalah kemanusiaan dan kehidupan sosial di tengah masyarakat.

Novel yang dikaji pada penelitian ini adalah novel "Midah si Manis Bergigi Emas" karya Pramoedya Ananta Toer. Novel ini dipilih karena berisi berbagai tingkah laku manusia dengan karakter yang khas dan selalu berkutat dengan masalah kemanusiaan, yaitu penderitaan, kegagalan, kebahagiaan, kekecewaan, dan perjuangan untuk hidup. Kekhasan novel ini terletak pada karakter yang ditampilkan tiap tokoh. Karakter tokoh utama yang berasal dari keluarga yang taat beragama tetapi mempunyai karakter yang berkebalikan dengan latar belakang keluarganya. Hal ini menjadi pelajaran bahwa karakter setiap orang berbeda-beda dan tidak harus mengikuti orang tuanya.

Penelitian yang berhubungan dengan ini pernah diteliti oleh Norsewan dengan judul tesisnya "Karakter Tokoh dalam Novel 'Anak Sejuta Bintang' Karya Akmal Nasery Basral”. Penelitian tersebut menghasilkan kesimpulan bahwa karakter tokoh dalam novel tersebut meliputi tanggung jawab, cinta keluarga, kerja keras, cinta terhadap negara, jujur, patriotisme, disiplin, dan taat beragama. Oleh Winny Afrianti dengan judul tesisnya "Karakterisasi Tokoh Utama dalam Novel 'Padang Bulan' Karya Andrea Hirata”. Penelitian ini menghasilkan kesimpulan bahwa tokoh dalam novel ada dua yaitu Enong dan Ikal. Tokoh Enong digambarkan secara langsung memiliki karakter tanggung jawab, cerdas, gigih, sabar, lugu, dan sederhana. Sedangkan tokoh Ikal digambarkan memiliki karakter 
keras kepala, gigih (tidak mudah putus asa), mudah cemburu, rendah diri (minder), dan pintar.

Penelitian selanjutnya oleh Ema Dwi Kotimah dengan judul skripsinya "Kepribadian Tokoh Utama Novel 'Midah si Manis Bergigi Emas' Karya Pramoedya Ananta Toer". Penelitian ini menghasilkan kesimpulan bahwa tokoh Midah memiliki kepribadian yang unik karena tidak semua orang memiliki pribadi dan pola pikir seperti dirinya dalam memandang dan memaknai kehidupan. Keunikan kepribadian tokoh Midah terletak pada cara ia memandang suatu kebebasan sebagai tujuan hidupnya. Oleh Wahyu Galih Mayasari dengan judul skripsinya "Aspek Moral dalam Novel 'Midah si Manis Bergigi Emas' Karya Pramoedya Ananta Toer". Penelitian ini menghasilkan kesimpulan bahwa tokoh Midah pada Novel tersebut kurang memperhatikan moral yang berlaku di tengah masyarakat. Moral atau nilai dipandangnya sebagai suatu pengekangan kebebasannya dalam berekspresi. Moral dalam pandangannya memiliki makna yang lain.

Penokohan yang diartikan sebagai cara pengarang menggambarkan mengenai watak atau karakter yang dimiliki tokoh dalam suatu cerita. Hal ini dapat diketahui melalui pelukisan pengarang tentang diri tokoh, keadaan lahir maupun batinnya yang dapat berupa pandangan hidupnya, sikap, keyakinan, adatistiadat, selain itu, penokohan merupakan salah satu unsur fiksi yang turut menentukan berhasil tidaknya suatu karya sastra. Untuk itu pengarang harus dapat melukiskan atau menggambarkan watak pelaku dengan sebaik-baiknya, yang mengungkapkan bahwa cara pengarang menggambarkan atau memunculkan tokohnya itu dapat berbagai macam. Pengarang menampilkan tokoh sebagai pelaku yang hanya hidup di alam mimpi, pelaku yang memiliki semangat perjuangan dalam mempertahankan hidupnya, pelaku yang memiliki cara sesuai dengan kehidupan manusia yang sebenarnya, maupun pelaku yang egois, kacau, dan mementingkan diri sendiri. Dalam cerita fiksi, pelaku itu dapat berupa manusia atau tokoh makhluk lain yang diberi sifat seperti manusia, misalnya kancil, kucing, sepatu, dan lain-lain. Para tokoh yang terdapat dalam sebuah 
cerita memiliki peranan yang berbeda-beda. Seorang tokoh yang memiliki peranan penting dalam suatu cerita disebut dengan tokoh inti atau tokoh utama. Sedangkan tokoh yang memiliki peranan tidak penting karena pemunculannya hanya melengkapi, melayani, mendukung pelaku utama disebut tokoh tambahan atau tokoh pembantu karena tokoh-tokoh dalam cerita rekaan dapat berfungsi sebagai subjek dan objek fokalisasi. Cara tokoh memandang, sebagai subjek fokalisasi, terhadap hal ikhwal di sekitarnya (objek fokalisasi) dapat dijadikan dasar kajian untuk mengais data yang menyangkut nilai dan perwujudan dalam sikap dan perilaku tokoh dalam batas tertentu, sekaligus dapat dipakai untuk mengungkap informasi tentang pendidikan, kelompok sosial, dan peran tokoh.

Menurut Ratna (2004: 318) penelitian secara tradisional pada umumnya menganalisis tokoh-tokoh sebagai unsur cerita sehingga tokoh-tokoh tampak sebagai bentuk konkret dan individual, sebagai person. Sebaliknya, menurut paradigma kontemporer, tokoh-tokoh harus dianalisis sebagai unsur rangkaian peristiwa yaitu, plot, dalam rangka menuju penyelesaian. Disinilah tokoh-tokoh menjadi aktor sekaligus menampilkan peranan-peranan sosial. Di sini pulalah tampil penokohan, sebagai karakterisasi. Dengan demikian, penokohan lahir melalui perkembangan psikologis tokoh, sebagai kelahiran pribadi yang bebas, bukan sama sekali atas dasar kemauan pengarang.

\section{METODE PENELITIAN}

Pendekatan yang digunakan dalam penelitian ini adalah kualitatif karena penyajian data pada penelitian ini berupa paparan atau narasi yang mendalam. Hamidi (2008: 55) menyatakan bahwa penelitian kualitatif memiliki ciri khas penyajian datanya dalam bentuk narasi, cerita mendalam atau rinci dari para responden hasil wawancara atau observari. Metode penelitian yang digunakan dalam mengkaji Novel "Midah si Manis Bergigi Emas" karya Pramoedya Ananta Toer adalah metode deskriptif kualitatif. Metode deskriptif kualitatif adalah prosedur penelitian yang menghasilkan data deskriptif yang berupa uraian cerita, ungkapan, pernyataan, perkataan, kata-kata tertulis dan perilaku yang diamati. 
Pada kegiatan penelitian, peneliti bertindak sebagai subjek yang memiliki pandangan dan nilai tertentu dalam menafsirkan isi novel. Dengan kata lain, peneliti bertindak sebagai instrumen penelitian. Data penelitian sastra adalah kata-kata, kalimat, dan wacana (Ratna, 2004: 47). Adapun data dalam penelitian ini berupa kata, kalimat, dan wacana yang terdapat dalam novel "Midah si Manis Bergigi Emas" karya Pramoedya Ananta Toer. Sumber data dalam penelitian ini adalah novel "Midah si Manis Bergigi Emas" karya Pramoedya Ananta Toer, diterbitkan oleh penerbit Lentera Dipantara. Jakarta. 2003.

Teknik pengumpulan data yang digunakan dalam penelitian ini adalah teknik dokumentasi. Teknik dokumentasi merupakan teknik yang dilakukan pada informasi yang berasal dari catatan penting baik dari lembaga atau organisasi maupun dari perorangan (Hamidi, 2008: 56). Pendokumentasian dilakukan pada novel "Midah si Manis Bergigi Emas" karya Pramoedya Ananta Toer. Teknik ini digunakan untuk mendapatkan data yang relevan dengan masalah yang diteliti.

\section{HASIL DAN PEMBAHASAN}

Tokoh yang terdapat pada novel "Midah si Manis Bergigi Emas" karya Pramoedya Ananta Toer berjumlah 14 orang. Karakter para tokoh akan dipaparkan sebagai berikut.

\section{Midah}

a) Midah memiliki sifat keras kepala dan teguh pada pendiriannya dalam memegang prinsip. Kutipan yang menunjukkan hal tersebut dalam novel sebagai berikut. "Anakku yang paling manis! Anakku yang keras hati! Sampai begitu engkau" (Toer, 2003: 67).

b) Mempunyai pendirian sendiri adalah berhadapan dengan pendapat umum. Kutipan yang menunjukkan hal tersebut dalam novel sebagai berikut. "Dan Midah terpancang kuat di atas bumi pendiriannya" (Toer, 2003: 121). 
c) Midah bersifat tegar dan tidak pantang menyerah dalam menjalani kehidupan yang sulit. Dalam keadaan sulit pun hatinya tetap kuat menahan setiap permasalahan. Kutipan yang menunjukkan hal tersebut dalam novel sebagai berikut. "Kehidupan keras dan kejam selama itu ia hadapi dengan keberanian, karena ada modalnya untuk berani. Karena da modal untuk menghadapinya: keyakinan, bahwa ia bisa juga hidup dari tangannya sendiri" (Toer, 2003: 86).

d) Tidak cekatan dalam bekerja karena terbiasa dengan kemudahan yang didapatnya di keluarganya. Kutipan yang menunjukkan hal tersebut dalam novel sebagai berikut.

"Engkau cantik, lagi pula tidak bisa diperintah orang. Engkau gampang tersinggung dan tidak cekatan" (Toer, 2003: 23).

e) Mudah tersinggung dan menyimpan rasa sakit hati dengan kata-kata maupun perbuatan orang lain. Kutipan yang menunjukkan hal tersebut dalam novel sebagai berikut.

"Engkau cantik, lagi pula tidak bisa diperintah orang. Engkau gampang tersinggung dan tidak cekatan" (Toer, 2003: 23).

"Ia masih ingat betapa sakit hatinya terhadap ayahnya atas tindakannya dahulu: piring-piringan hitam keroncong yang dicintainya ditarik dengan kasarnya kemudian dibanting ke lantai: pecah-belah" (Toer, 2003: 26).

f) Memiliki kesetiaan terhadap pasangan. Kutipan yang menunjukkan hal tersebut dalam novel sebagai berikut.

"Tapi aku tidak sanggup melepaskan cintaku padanya (Toer, 2003: 112).Wanita akhirnya menjadi pemeluk kapercayaan cinta yang fanatik" (Toer, 2003: 121).

\section{Nyonya Abdul}

a) Nyonya Abdul memiliki sifat acuh tak acuh terhadap kondisi di sekitarnya meskipun hal tersebut berhubungan dengan anaknya. Kutipan yang menunjukkan hal tersebut dalam novel sebagai berikut.

"Istri Abdul yang tidak pernah ikut campur dalam segala perkara dan tidak pernah menyumbangkan suara" (Toer, 2003: 
71). “Aku bersalah karena tidak pernah memperdulikannya. Tapi sekarang semuanya bisa diperbaiki" (Toer, 2003: 104).

b) Memiliki sifat penakut terutama kepada suami, sehingga ia tidak berani melakukan tindakan apa pun tanpa perintah suaminya. Kutipan yang menunjukkan hal tersebut dalam novel sebagai berikut. "Di pertengahan jalan baru ia ingat bahwa jam enam suaminya nanti datang. Dia akan marah. Dan ia takut hati suaminya terganggu" (Toer, 2003: 99).

c) Nyonya Abdul adalah seorang yang taat beragama. Kutipan yang menunjukkan hal tersebut dalam novel sebagai berikut. "Dalam keadaan kurang makan dan kurang tidur wanita itu terus berdoa dan tiap sampai waktunya ia bersembahyang" (Toer, 2003: 74).

\section{Riah}

a) Riah memiliki sifat penyayang, baik hati, dan keibuan, serta bisa bersikap dewasa dalam menghadapi persoalan hidup. Kutipan yang menunjukkan hal tersebut dalam novel sebagai berikut.

"Orang sebagai Riah yang tak ada lain modalnya daripada kejujurannya sendiri, selalu mencoba berbuat baik untuk orang lain" (Toer, 2003: 24).

"Midah, anakku! Suara itu memberi belaian yang manis di hatinya yang diperkeras oleh keadaannya selama itu" (Toer, 2003: 62).

b) Memiliki sifat jujur. Kutipan yang menunjukkan hal tersebut dalam novel sebagai berikut. "Orang sebagai Riah yang tak ada lain modalnya daripada kejujurannya sendiri, selalu mencoba berbuat baik untuk orang lain" (Toer, 2003: 24).

c) Riah adalah orang yang taat memegang norma-norma agama maupun norma kesusilaan di masyarakat. Kutipan yang menunjukkan hal tersebut dalam novel sebagai berikut. "Midah, orang tuamu adalah orang-orang yang menaati perintah Tuhan. Dan aku harap engkau tidak menjauhi jalan mereka" (Toer, 2003: 26). 


\section{Rois}

a) Rois bersifat dewasa dan dapat dipercaya dalam memimpin rombongan. Kutipan yang menunjukkan hal tersebut dalam novel sebagai berikut.

"Manis, dalam rombongan seperti ini selamanya ada yang mesti dipercaya. Dan orang itu adalah kepalanya. Kalau tidak dapat dipercaya, dia sudah lama diusir dari rombongan" (Toer, 2003: 41).

b) Perhatian. Kutipan yang menunjukkan hal tersebut dalam novel sebagai berikut. "Tiba-tiba Rois kepala rombongan, memperhatikannya lagi” (Toer, 2003: 35).

"Aku mengerti juga, Manis. Tetapi engkau harus pula ingat, tiada bekerja engkau pun tiada menerima nafkah. ... Tapi toh aku usahakan agar engkau tetap menerima nafkah sekalipun tidak mungkin sebanyak yang biasa engkau terima" (Toer, 2003: 46-47).

c) Mampu melindungi anggota rombongan khususnya yang lemah. Kutipan yang menunjukkan hal tersebut dalam novel sebagai berikut.

"Karena itu aku datang menolongmu. Kepala rombongan itu duduk di dekatnya, jangan takut. Aku juga punya anak. Dan tiap lelaki yang tidak menghormati makhluk yang masih di kandungkan tidak patut lebih lama hidup di atas dunia ini" (Toer, 2003: 41).

d) Rois mempunyai sisi buruk di samping sifatnya yang baik yaitu mempunyai niat yang lain dibalik kebaikannyaKutipan yang menunjukkan hal tersebut dalam novel sebagai berikut. "Kepala rombongan sekali-dua kali mengulangi lamarannnya. Tetapi Simanis tetap menolak. ... Sikap-sikap yang keluar dari alasan-alasan itu menjengkelkan kepala rombongan dan dari jengkel akhirnya berubah menjadi benci” (Toer, 2003: 61-62).

\section{Nyonya Rumah}

a) Nyonya rumah bersifat tegas namun penyayang serta baik hati. Kutipan yang menunjukkan hal tersebut dalam novel sebagai berikut. 
"Nyonya rumah masuk dan membawakan minuman. Aku percaya nyonya orang baik-baik yang akan ikut memelihara kesopanan rumah tanggaku" (Toer, 2003: 82).

b) Patuh terhadap norma-norma yang berlaku di masyarakat. Kutipan yang menunjukkan hal tersebut dalam novel sebagai berikut.

"Kau telah pernah kawin. Engkau telah punya anak. Tidak mungkin itu karena cinta. Kalau engkau tahu, Midah, bagaimana rasa hatiku. Engkau telah menodai kehormatan rumah tanggaku. ... Rumahku jadi rumah cabul! ... Dan engkau cabulnya! ... Tambah lama suara Nyonya Rumah tambah meningkat. ... Kalau engkau tak kawini Ahmad, seru Nyonya Rumah sekali lagi, sekarang juga engkau harus angkat pantat dari sini" (Toer, 2003: 112-113).

c) Nyonya rumah mempunyai kecintaan terhadap musik. Kutipan yang menunjukkan hal tersebut dalam novel sebagai berikut.

"Sayang tak ada gendang di sini, nyonya rumah menyesali. Gendangku dipinjam tetangga untuk main gambus. Mendiang suamiku dahulu mempunyai harmonium. Tiap malam sehabis kerja dimainkannya (Toer, 2003: 91). Nyonya, aku sendiri suka menyanyi" (Toer, 2003: 103).

\section{Rodjali}

a) Rodjali masih lugu atau belum mengerti permasalahan orang di sekitarnya. Kutipan yang menunjukkan hal tersebut dalam novel sebagai berikut.

"Djali, Midah berbisik, ibu mau pergi. Engkau tinggal di sini dengan nenek. Anak itu tertawa” (Toer, 2003: 127).

b) Anak yang baik dalam pandangan masyarakat karena dia lahir dengan status yang jelas. Kutipan yang menunjukkan hal tersebut dalam novel sebagai berikut.

"Setidak-tidaknya dia anak sah, walaupun lahir beserta kebencianku pada Terbus, dia akan mendapat rawatan yang baik dari neneknya, dari kakeknya, dan dari bibinya.... Rodjali akan selamat di tangan nenek dan kakeknya. Dia takkan 
menghadapi musuh. Dia takkan menghadapi hukuman orang yang kenal riwayatnya. Dia lahir sebagai warga norma dan kesusilaan pergaulan" (Toer, 2003: 126).

\section{Hadji Abdul}

a) Memiliki sifat tempramental. Kutipan yang menunjukkan hal tersebut dalam novel sebagai berikut.

"Jauh-jauh Bapak sudah berteriak dengan suara kejam: haram! Haram! Siapa memutar lagu itu di rumah? ... Ia tampar gadis itu pada pipinya. ... Siapa mengajari engkau menyanyi lagu haram ini? Tangannnya telah melayang untuk sekali lagi mendarat di kepala Midah" (Toer, 2003: 18).

"Siapa yang mengajar? Jawab! Kalau tidak, aku banting kau di lantai" (Toer, 2003: 19).

b) Merasa diri paling shaleh, paling dikasihi Tuhan, paling benar, merasa diri lebih baik dari orang lain. Kutipan yang menunjukkan hal tersebut dalam novel sebagai berikut.

"Ia merasa sudah menerima sebagian terbesar

dambaannya dari Tuhannya" (Toer, 2003: 12).

"Ia terus-menerus berzikir. Kadang-kadang hingga matahari yang kemarin telah datang lagi di ufuk timur" (Toer, 2003: 12).

c) Gila pujian dan riya. Kutipan yang menunjukkan hal tersebut dalam novel sebagai berikut.

"Orang yang dahulu selalu merasa puas akan dirinya, akan kejayaan dan kebenaran dirinya ini kini mengalami ketumbangan segala: perusahaan, iman, hari depan, dan kebesaran yang hendak dipamerkannya di kampung asalnya Cibatok" (Toer, 2003: 68). "Abdul merasa bersalah karena gila pujian” (Toer, 2003: 103).

\section{Hadji Terbus}

Hadji Terbus berasal dari Cibatok, kaya dan terpandang, berasal dari kalangan menengah atas, berpendidikan, taat beragama, serta memiliki istri banyak tersebar di seluruh Cibatok. Memiliki sifat yang serakah dan sombong. Kutipan yang menunjukkan hal tersebut dalam novel sebagai berikut. 
"Ia punya sawah banyak, kerbau berpuluh-puluh, ibadatnya kuat" (Toer, 2003: 20). "Hadji Terbus dari Cibatok, seorang yang berperawakan gagah, tegap, berkumis lebat, dan bermata tajam. Perutnya yang menonjol ke depan dan langkahnya yang tidak pernah berisi kebimbangan, menandakan ia seorang lelaki yang mahir dalam memerintah dan biasa hidup dalam kekayaan" (Toer, 2003: 20). "Hadji Terbus bukan bujang dan bukan muda. Bininya telah tersebar banyak di seluruh Cibatok" (Toer, 2003: 21).

\section{Mimin}

a) Memiliki sifat cemburuan. Kutipan yang menunjukkan hal tersebut dalam novel sebagai berikut. "Nampak seri cemburu memancar di wajah Min dan perempuan bergigi emas" (Toer, 2003: 32). "Bengawan Solo? Tanya Min mencoba mematahkan cemburu hatinya" (Toer, 2003: 35).

b) Menyimpan dendam dalam hati Kutipan yang menunjukkan hal tersebut dalam novel sebagai berikut. "Mimin kurus yang dihembalang oleh kekecewaannnya dahulu lambat laun menyimpan dendam dalam hati" (Toer, 2003: 47).

c) Memiliki nafsu tinggi. Kutipan yang menunjukkan hal tersebut dalam novel sebagai berikut. "Mengapa takut padaku? Suara lelaki disampingnya. Aku sudah dewasa seperti yang lain-lain. ... Mimin kurus menjadi panas oleh suara-suara itu dan tubuhnya diterkamnya mentah-mentah" (Toer, 2003: 39-40).

\section{Nini}

a) Nini bersifat kasar dan tempramental. Sering mengeluarkan kata-kata yang kasar ketika sedang marah. Kutipan yang menunjukkan hal tersebut dalam novel sebagai berikut. "Bangsat! Kau kira apa aku ini?" (Toer, 2003: 33). "Dan kejadian itu disambut dengan ejekan yang lebih hebat oleh Nini. ... Dia ikut-ikut bergigi emas! Teriak Nini dengan sengitnya. ... Sebuah tempeleng melayang pada pipi Midah. Ia terjatuh di samping anaknya. Tiru-tiru pakai gigi emas. Tidak laku gigimu itu! Teriak Nini” (Toer, 2003: 64-65). 
b) Memiliki sifat cemburu yang tinggi. Kutipan yang menunjukkan hal tersebut dalam novel sebagai berikut. "Sabar, Nini. Kalau engkau begitu cemburuan, aku takut engkau jatuh jadi pengemis di Pasar Senen" (Toer, 2003: 33). "Kalau hanya datang untuk dia, tuan tidak perlu datang, teriak Nini” (Toer, 2003: 61).

c) Selain sifat cemburu yang tinggi, Nini juga memiliki sifat dengki terutama terhadap saingannya. Kutipan yang menunjukkan hal tersebut dalam novel sebagai berikut. "Juga Nini, yang memandang Simanis sebagai saingannya, berpihak kepadanya" (Toer, 2003: 47).

d) Mudah tersinggung.Kutipan yang menunjukkan hal tersebut dalam novel sebagai berikut. "Dia sudah tua, tidak menarik pendengar lagi. Suaranya pun tak sebagus engkau. Apa! Habis manis sepah dibuang!" (Toer, 2003: 32).

\section{Mak Pecak}

Mak Pecak adalah pemain gitar dalam rombongan pengamen keroncong, tidak berpendidikan, memiliki nafsu tinggi, dan munafik karena hanya memihak kepada yang memberikan keuntungan kepadanya.

Kutipan yang menunjukkan hal tersebut dalam novel sebagai berikut.

“... menjadi panas oleh suara-suara itu dan tubuhnya diterkamnya mentah

mentah. Kini ia menghadapi kenyataan sebagai wanita dalam kerumunan

pria kamar gelap... kalau kalah minggir saja, aku bisa menggantikan" (Toer,

2003: 40).

"Dua orang lagi, yang juga mengalami kegagalan dalam percobaannya untuk mempergunakan jenis Midah, berpihak belaka pada Nini dan Mimin" (Toer, 2003: 47). 


\section{Dul Gendang}

Dul Gendang adalah pemain gendang dalam rombongan pengamen keroncong, tidak berpendidikan, memiliki nafsu tinggi, dan munafik karena hanya memihak kepada yang memberikan keuntungan kepadanya. Kutipan yang menunjukkan hal tersebut dalam novel sebagai berikut.

“... menjadi panas oleh suara-suara itu dan tubuhnya diterkamnya mentah-mentah. Kini ia menghadapi kenyataan sebagai wanita dalam kerumunan pria kamar gelap... kalau kalah minggir saja, aku bisa menggantikan" (Toer, 2003: 40).

"Dua orang lagi, yang juga mengalami kegagalan dalam percobaannya untuk mempergunakan jenis Midah, berpihak belaka pada Nini dan Mimin" (Toer, 2003: 47).

\section{Bidan}

a) Bidan yang bekerja di rumah bersalin bersifat sinis kepada pasien. Kutipan yang menunjukkan hal tersebut dalam novel sebagai berikut.

"Kenapa anakmu? Sambut seorang bidan sambil tersenyum mengejek" (Toer, 2003: 50). "Jadi harus anak empok dianggap anak haram" (Toer, 2003: 52).

b) Selain bersifat sinis, bidan di rumah bersalin tersebut juga bersifat kasar terhadap pasien. Kutipan yang menunjukkan hal tersebut dalam novel sebagai berikut.

"Kami tidak terima orang. Semua tempat sudah dipesan. ... Pulang saja. Kan ada dukun kampung di sana? ... Pulang buruan!” (Toer, 2003: 49).

"Seorang bidan berdiri di dekatnya. Ia memandanginya lama-lama. ... Aku disini kerja bukan main-main" (Toer, 2003: 49-50).

c) Suka meremehkan orang lain atau menganggap orang lain lebih rendah. Kutipan yang menunjukkan hal tersebut dalam novel sebagai berikut.

"Jadi harus anak empok dianggap anak haram? ... Bidan itu pun pergi dengan paras muram” (Toer, 2003: 52-53). 
"Ia diantarkan ke kantor, dan paras-paras masam menerimanya dengan dingin" (Toer, 2003: 55).

\section{Ahmad}

a) Ahmad adalah seorang polisi lalu lintas yang sering bertugas di sekitar penginapan Midah di kawasan Jatinegara Kutipan yang menunjukkan hal tersebut dalam novel sebagai berikut. "Dari Depot kemudian muncul polisi lalu lintas yang telah dikenalnya" (Toer, 2003: 77).

"Apa harus aku sebut kau? Ahmad. Dan siapa namamu sebenarnya?" (Toer, 2003: 81).

b) Selain seorang polisi lalu lintas, Ahmad juga seorang pemusik dan seniman keroncong yang biasa menyanyi di radio. Kutipan yang menunjukkan hal tersebut dalam novel sebagai berikut.

"Ah, saudara, aku sendiri tukang musik juga" (Toer, 2003: 60).

"Apa yang tidak dikenal? Walau kecil-kecilan, kita berdua adalah seniman. Dan tiap seniman adalah kawan satu sama lain" (Toer, 2003: 79).

c) Ahmad memiliki sifat baik hati. Kutipan yang menunjukkan hal tersebut dalam novel sebagai berikut. "Baiklah harap dia jangan banyak diganggu. Dia baru melahirkan dan sebaiknya mendapat perawatan yang baik. Tetapi sebagian dari kalian memusuhinya. Itu aku tidak setuju" (Toer, 20003: 61).

d) Ahmad memiliki sifat ramah. Kutipan yang menunjukkan hal tersebut dalam novel sebagai berikut. "Keramahannya itu melenyapkan kemalu-maluan Midah terhadapnya" (Toer, 2003: 78).

e) Ahmad adalah seorang periang dan riang gembira. Hari-harinya dilalui dengan tanpa beban. Kutipan yang menunjukkan hal tersebut dalam novel sebagai berikut. "Ahmad tertawa girang" (Toer, 2003: 82). "Mengerti aku sekarang, polisi itu menjadi girang kembali” (Toer, 2003: 85).

f) Ahmad mempunyai sifat yang lurus. Setiap perbuatannya berada di jalur kebaikan untuk membantu Midah. Kutipan yang menunjukkan hal tersebut dalam novel sebagai berikut. “... begitu lurus hati dia. Begitu terus terang" (Toer, 
2003: 83).

"Ahmad dengan sikapnya yang lurus dan tingkah lakunya yang bebas" (Toer, 2003: 86).

g) Ahmad bertingkah laku bebas sesuai dengan panggilan jiwa seorang seniman. Ia bertindak tidak berlandaskan pada aturan-aturan yang berlaku. Kutipan yang menunjukkan hal tersebut dalam novel sebagai berikut.

"Hatinya lega menemui seorang bebas pula sebagai polisi lalu lintas yang ada di dekatnya itu" (Toer, 2003: 80).

"Ahmad dengan sikapnya yang lurus dan tingkah lakunya yang bebas" (Toer, 2003: 86).

h) Ahmad adalah seorang yang pengecut ketika dimintai pertanggung jawaban atas perbutaannya. Kutipan yang menunjukkan hal tersebut dalam novel sebagai berikut. "Bukan engkau tidak mau mengakui anakmu sendiri. Bukannya engkau membimbangkan cintaku padamu. Tapi kini aku mengetahui. Seorang yang kucintai itu adalah pengecut yang tidak punya keberanian sedikitpun juga!' (Toer, 2003: 110).

i) Ahmad memiliki sifat tidak bertanggung jawab dengan tidak mengakui anak yang ada dalam kandungan Midah. Kutipan yang menunjukkan hal tersebut dalam novel sebagai berikut. "Aku tidak keberatan apabila engkau tak mau mengakui anakmu sendiri. Aku pun tidak keberatan kau tuduh bercampur dengan lelaki lain" (Toer, 2003: 110). "Hanya satu yang tidak akan terlupa olehmu. Anak ini adalah anakmu” (Toer, 2003: 110).

j) Ahmad memiliki sifat egois untuk menjaga nama baiknya di mata masyarakat. Kutipan yang menunjukkan hal tersebut dalam novel sebagai berikut.

"Engkau terlampau memikirkan dirimu sendiri" (Toer, 2003: 94).

"Baiklah semua ini aku ambil untuk diriku sendiri. Dan engkau Kak, engkau boleh terpandang sebagai orang baik-baik untuk selama-lamanya. Biarlah segala yang kotor aku ambil sebagai tanggung jawabku sendiri” (Toer, 2003: 110). 
k) Ahmad berasal dari kalangan menengah atas, berasal dari keluarga baik-baik, serta berpendidikan. Sebagai seorang polisi ia terpandang di tengah masyarakat. Kutipan yang menunjukkan hal tersebut dalam novel sebagai berikut. " $A k u$ tahu engkau orang baik-baik, engkau anak dari keluarga baikbaik" (Toer, 2003: 108). "Kak, engkau boleh terpandang sebagai orang baik-baik untuk selama-lamanya" (Toer, 2003: 110).

\section{PENUTUP}

Berdasarkan hasil penelitian yang telah dipaparkan, dapat disimpulkan bahwa tokoh-tokoh yang terdapat pada novel "Midah si Manis Bergigi Emas" karya Pramoedya Ananta Toer berjumlah 14 orang yaitu, 1) Midah dengan karakternya yaitu keras kepala, baik hati, tegar, kuat hatinya, tidak pantang menyerah, mudah tersinggung, teguh pada pendirian, tidak cekatan, dan setia; 2) Nyonya Abdul dengan karakternya yaitu acuh tak acuh, terlalu takut pada suami, dan taat beragama; 3) Riah dengan karakternya yaitu penyayang, baik hati, dewasa, keibuan, dan jujur. Riah hanya tahu mengenai kebaikan di dunia serta selalu memegang norma yang baik; 4) Rois dengan karakternya yaitu dewasa, dapat dipercaya, bisa melindungi yang lemah, baik dan perhatian terhadap Midah, tetapi memiliki maksud tersendiri karena ingin menikahi Midah; 5) Nyonya rumah dengan karakternya yaitu tegas namun penyayang, dan patuh dengan norma yang berlaku di masyarakat; 6) Rodjali dengan karakternya yaitu masih lugu atau belum mengerti permasalahan orang di sekitarnya; 7) Hadji Abdul dengan karakternya yaitu tempramental, sombong, serakah, gila pujian, merasa diri paling shaleh, paling dikasihi Tuhan, paling benar, merasa diri lebih baik dari orang lain; 8) Hadji Terbus dengan karakternya yaitu kaya dan terpandang, taat beragama, serta memiliki istri yang banyak; 9) Mimin dengan karakternya yaitu tidak berpendidikan, memiliki sifat cemburuan, suka menyimpan dendam, dan memiliki nafsu tinggi; 10) Nini dengan karakternya yaitu cemburu, iri, dengki, tempramental, dan mudah tersinggung; 11) Mak Pecak dengan karakternya yaitu tidak berpendidikan, memiliki nafsu tinggi, dan munafik; 12) Dul 
Gendang dengan karakternya yaitu tidak berpendidikan, memiliki nafsu tinggi, dan munafik; 13) Bidan dengan karakternya yaitu kasar, sinis, dan meremehkan orang lain; 14) Ahmad dengan karakternya yaitu ramah, baik hati pada awalnya, periang tanpa beban, sikapnya lurus, tingkah lakunya bebas, pengecut, tidak memiliki rasa tanggung jawab, dan egois.

Berdasarkan hasil penelitian, saran yang bisa diberikan sebagai berikut. Pertama, penelitian ini masih meneliti sebagian kecil aspek dalam novel, masih banyak aspek lain yang perlu diteliti oleh peneliti lain seperti tema dan alur. Kedua, hasil penelitian ini diharapkan bisa menjadi referensi bagi pengajaran sastra di sekolah, terutama materi yang berhubungan dengan sastra dan unsur-unsurnya, khususnya unsur intrinsik tokoh maupun karakter tokoh.

\section{DAFTAR PUSTAKA}

Afrianti, W. (2012). Karakterisasi Tokoh Utama dalam Novel Padang Bulan Karya Andrea Hirata. Banjarmasin: Pascasarjana Universitas Lambung Mangkurat Banjarmasin.

Kotimah, E. D. (2012). Kepribadian Tokoh Utama Novel Midah si Manis Bergigi Emas Karya Pramoedya Ananta Toer. Semarang: Universitas Negeri Semarang.

Norsewan. (2012). Karakter Tokoh dalam Novel Anak Sejuta Bintang Karya Akmal Nasery Basral. Banjarmasin: Pascasarjana Universitas Lambung Mangkurat Banjarmasin.

Ratna, N. K. (2004). Teori, Metode, dan Teknik Penelitian Sastra. Yogyakarta: Pustaka Pelajar.

Toer, P. A. (2003). Midah, si Manis Bergigi Emas. Jakarta: Lentera Dipantara. 